\title{
Board of Directors, Information Asymmetry, and Intellectual Capital Disclosure among Banks in Gulf Co-Operation Council
}

\author{
(Lembaga Pengarah, Maklumat Asimetri dan Pendedahan Modal Intelek dalam Kalangan \\ Bank di Majlis Kerjasama Teluk) \\ Zuaini Ishak \\ Abood Mohammad Al-Ebel \\ (School of Accounting, College of Business, Universiti Utara Malaysia)
}

\begin{abstract}
The main thrust of this paper is to examine the intellectual capital (IC) disclosure of 137 listed banks in Gulf Co-operation Council (GCC) nations using a content analysis approach. Instead of examining the effect of board characteristics in isolation from each other, this study extends previous research on the determinants of IC disclosure by considering board effectiveness score in relation to IC disclosure. Moreover, this study extends previous studies in board-IC disclosure relationship by investigating the hypothesized impact of information asymmetry in moderating this relationship. Our findings show that IC disclosure is positively associated with the effectiveness of board of directors. In addition, our study provides evidence that the level of information asymmetry in GCC bank moderates the relationship between board effectiveness and IC disclosure. The finding is important for policymakers as it confirms that the effectiveness of board of directors in protecting the investors depends on the level of information asymmetry.
\end{abstract}

Keywords: Board of Directors; information asymmetry; intellectual capital disclosure; banks; Gulf Co-Operation Council

ABSTRAK

Teras utama kertas ini adalah untuk mengkaji pendedahan modal intelek (IC) oleh 137 bank tersenarai di negaranegara anggota Majlis Kerjasama Teluk (GCC) menggunakan pendekatan analisis kandungan. Daripada mengkaji kesan ciri-ciri lembaga secara berasingan, kajian ini sebalinya meneruskan penyelidikan sebelum ini mengenai penentu pendedahan IC dengan mempertimbangkan skor keberkesanan lembaga berhubung dengan pendedahan IC. Selain itu, kajian ini meneruskan kajian terdahulu mengenai hubungan lembaga pengarah-pendedahan IC dengan mengkaji kesan hipotesis terhadap maklumat asimetri dalam memoderasikan hubungan ini. Penemuan kami menunjukkan bahawa pendedahan IC mempunyai hubungan positif dengan keberkesanan lembaga pengarah. Di samping itu,kajian kami turut membekalkan bukti bahawa tahap maklumat asimetri bank di GCC moderasikan hubungan antara keberkesanan lembaga pengarah dengan pendedahan IC. Penemuan ini adalah penting bagi penggubal dasar kerana ia mengesahkan yang keberkesanan lembaga pengarah dalam melindungi pelabur adalah bergantung kepada tahap maklumat asimetri.

Kata kunci: Lembaga Pengarah; maklumat asimetri; pendedahan modal intelek; bank; Majlis Kerjasama Teluk

\section{INTRODUCTION}

Voluntary disclosure and board monitoring activities are both viewed by agency theorists as two effective mechanisms to reduce agency costs and ensure improved protection of the company's investors (see Jensen \& Meckling 1976; Fama \& Jensen 1983). Young et al. (2008) argued that one of the ways to protect shareholders especially the minority shareholders in countries with weak legal protection is to have higher disclosure quality and transparency. Thus, voluntary disclosure is considered useful to enhance the protection of such outsiders because it provides a signal to the minority shareholders whether the firm is committed to the treatment of its shareholders, in a fair and equitable manner (Chobpichien, Haron \& Ibrahim 2008). This paper focuses on a particular type of voluntary disclosure, which is intellectual capital (IC) disclosure since IC is a key driver of the company's competitive advantage and disclosing it will allow the shareholders to better anticipate the company risk (Cerbioni \& Parbonetti 2007).

Based on the economic theory framework, particularly agency theory and hegemony theory, we examine the relationship between IC disclosure and board characteristics among the listed banks in Gulf Co-Operation Council (GCC). IC disclosure is expected to mitigate opportunistic behavior and information asymmetry problem (Cerbioni $\&$ Parbonetti 2007). Therefore, voluntary disclosure of IC primarily works as one of governance mechanisms. In addition to the voluntary disclosure, the board of directors is an internal corporate governance mechanism that protects shareholders' interest by monitoring management 
behavior. The board generally makes decision on behalf of shareholders. Fama and Jensen (1983) also argued that the board of directors is needed to minimize agency cost, by aligning the interests of manager and shareholders, as well as enhancing the level of disclosure. Cerbioni and Parbonetti (2007) claimed that internal governance works complementarily to corporate disclosures, and the application of more governance mechanisms will assist the company to maintain its internal control. They claimed further that it will work as an "intensive monitoring package" to reduce opportunistic behaviors of management and information asymmetry. Managers should not withhold information for their own benefit, so the level of voluntary disclosure in company's annual report is expected to increase. However, previous studies that have examined the relationship between board of director's characteristics and voluntary disclosure of IC practice (e.g. Cerbioni \& Parbonetti 2007; Singh \& Van der Zahn 2008; Li, Pike \& Haniffa 2008) found somewhat mixed results. The reasons for the mixed results in these studies could be due to their examination of the effect of governance mechanisms in isolation from each other (Ward, Brown \& Rodriguez 2009).

Ward et al. (2009) argued that previous studies considered each mechanism separately in addressing the agency problems by ignoring the idea that the effectiveness of a mechanism depends on other mechanisms. In addition, Agrawal and Knoeber (1996) argued that the results of the effectiveness of an individual mechanism might be misleading as the effectiveness of the individual mechanism could disappear if a number of mechanisms are combined. Based on the idea that the internal governance mechanisms and disclosures are complementary to each other, the effectiveness of corporate governance mechanisms may be achieved through various channels (Cai, Liu \& Qian 2008) and the effectiveness of a particular mechanism may depend on the effectiveness of others (Rediker \& Seth 1995). Hence, we suggest the use of several board characteristics to measure the board effectiveness as a factor to increase the level of voluntary disclosure.

Having said the important of IC disclosure and that several boards characteristic are needed as effective governance mechanisms to monitor management behavior, this study finds it important to examine the effectiveness of board characteristics on the IC disclosure. Specifically, this study examines the relationship between score for board effectiveness and IC disclosure. However, it should be noted that the intensity of board of directors' effectiveness in monitoring the conflict between the majority and minority of shareholders is much affected by information asymmetry (Boone et al. 2007; Linck, Netter \& Yang 2008). Thus, in the weak legal protection of minority interests' environment, the board of directors' monitoring is limited internally through information asymmetry directed by management. This argument supports the hegemony theory. Further, Chen and Nowland (2010) stated that information asymmetry makes the monitoring activities conducted by the board of directors less effective. Transparency in the annual reports could not be achieved by the intensity of board of directors' monitoring in companies where an information asymmetry is high. Therefore, this study considers it essential to examine the moderation effect of information asymmetry on the relationship between effectiveness of board of directors on IC disclosure.

All GCC countries (the Kingdom of Bahrain, the State of Kuwait, the State of Qatar, the Sultanate of Oman, the State of United Arab Emirates and the Kingdom of Saudi Arabia) have a mature, efficient, stable, and profitable banking system. These countries share some common economic, cultural, and political similarities, which by far outweigh any differences they might have (Al-Muharrami, Matthews \& Khabari 2006). In 2008, the GCC countries' economy accounted for around 1.8 per cent of the world's total GDP of about USD61 trillion (Al-Hassan, Oulidi \& Khamis 2010). However, the empirical study in GCC countries is lacking.

Specifically, the banking sector in GCC is selected for this study because in GCC countries, banking sector is one of the largest sectors and there are more bank stocks traded in GCC stock markets than stocks of any other industry. Banking sector continues to be well-capitalized across the board with capital adequacy ratios of above minimum standards and comfortable leverage ratios by international comparisons (Al-Hassan et al. 2010). The business nature of the banking sector is "intellectually" intensive and for this reason, voluntary disclosure of IC is helpful for shareholders and corporate board is expected to play important role to increase the level of IC disclosure (Li, Mangena \& Pike 2012). In addition, by focusing on a single industry, it allows us to control the differential effects of regulation in making the analysis. It also gives us the opportunity to assess the influence of the board of directors' effectiveness on the level of IC disclosure of GCC-listed banks more directly. The competition in the banking sector at GCC is high and the corporate governance in this sector is better than other sectors. Despite this, however, the information asymmetry is still high while the level of disclosure is low in the banking sector (Chahine 2007).

The present study is significant as it contributes to the empirical literature on the evidence of relationship between the effectiveness of board of directors and IC disclosure. The effectiveness of the board is examined as a bundle of mechanisms. The results show that IC disclosure is greater for banks with a high score of effectiveness of board of directors. Secondly, this study provides the evidence that the relationship between the score of effectiveness of board of directors and IC disclosure is moderated by the level of information asymmetry. This means that the ability of board in enforcing the management to disclose more information about IC is affected by level of information asymmetry.

The remainder of the paper is structured in the following sequence. The next section is the literature 
review on IC disclosure, board of directors' effectiveness, and information asymmetry and then followed by hypotheses development. Section 3 presents research method and the findings are reported in Section 4. The last section of this paper summarizes its key findings, and after discussing some of its limitations, a number of further research topics are suggested.

\section{LITERATURE REVIEW AND HYPOTHESES DEVELOPMENT}

\section{INTELLECTUAL CAPITAL DISCLOSURE}

The researchers and analysts have not reached unanimous agreement on the definition of IC disclosure and its components. However, one of the most widely accepted definitions of intellectual capital, which is supported by a number of prominent authors (Sveiby 1997; Brennan \& Connell 2000; Sullivan 2000), is formed by three sub constructs: internal capital, external capital, and human capital. Internal capitals include patents, copyright, management philosophy, technology, and administrative systems. On the other hand, external capitals include customer capital comprising relationships with customers and suppliers, brand names, trademarks, and reputation. Next are human capitals which refer to employees' competence such as skills, knowledge, qualification, experience.

Disclosing information about IC in the corporate annual report is not costless. Williams (2001) argued that voluntary disclosure of IC could affect the competitive advantage of company since it provides signal to competitors of possible value-creating opportunities. According to Vergauwen and Alem (2005), a firm may be at the competitive disadvantage when it discloses sensitive information to outside investors. However, from the literature review, it could be deduced that disclosure of IC has advantages for company, investors, and markets. For example, IC disclosure can help organizations to formulate their strategies, to diversify and expand decisions, and to use as a basis for compensations (Marr, Mouritsen \& Bukh 2003). The disclosure provides the information about the real value and future performance of a company. Hence, it is considered as relevant information for investors and users (Bukh et al. 2005). Furthermore, IC disclosure may be considered to resolve uncertainty about the firm which in turn leads to the increase in the stock price, reduction in volatility of stock prices and a decrease in capital cost (Kristandl \& Bontis 2007). Recognizing these advantages of IC disclosure, several attempts have been made in reporting IC. From these attempts, several models have been produced to measure and report the IC. For example, Kaplan and Norton's Balanced Scorecard (Kaplan \& Norton 1992), Sveiby's Intangible Assets Monitor (Sveiby 1997), and Skandia's Value Scheme (Edvinsson $\&$ Malone 1997) are among the most popular models used to construct reports on intellectual capital.
Reviewing of literature reveals that majority of studies used Sveiby's (1997) framework that categorizes IC into three categories namely, internal structure, external structure, and employee competence. For example, modifying Sveiby (1997) framework of IC by renaming the categories of IC to internal capital, external capital, and human capital, Guthrie and Petty (2000) examined the level of IC disclosure in Australia. The IC reporting framework suggested by Guthrie and Petty (2000) has been followed by several authors in many countries such as Brennan (2001) in Ireland, Bozzolan, Favotto and Ricceri (2003) in Italy, Vandemaele, Vergauwen and Smits (2005) in Netherlands, Sweden and UK, Li et al. (2008) in UK, and Yi and Davey (2010) in China.

Prior research mainly reflects the experiences from developed and emerging markets which have different culture, socio-economic situation, and political norms from those predominant Arab countries, particularly the GCC countries. Consequently, empirical investigations or surveys that have been carried out in the GCC region have been limited. Furthermore, majority of previous studies have concentrated on investigating the relationship between corporate governance and the IC disclosure of non-financial companies. In spite of this, IC is considered one of the major determinants of competitive advantage in banking sectors (Ranjith 2007) while corporate governance is also important in the banking sectors more than any other sectors because of the effect of this sector on other sectors in the country (OECD 2009). Thus, this study extends the previous research on the determinants of IC disclosure by considering board effectiveness score in relation to IC disclosure. Moreover, this study extends the previous studies in board-IC disclosure relationship by investigating the hypothesized impact of information asymmetry in moderating this relationship.

\section{EFFECTIVENESS OF BOARD OF DIRECTORS AND IC DISCLOSURE}

The board of directors is one of the important elements in internal corporate governance mechanisms. The board plays the key monitoring role in dealing with agency problems (Chobpichien et al. 2008; Singh \& Van der Zahn 2008; Aktaruddin et al. 2009). Fama and Jensen (1983) argued that by monitoring and controlling the management, the board of directors can reduce agency conflicts where managers may have their own preferences and always fail to act on behalf of the shareholders. Moreover, it can be argued that the board of directors plays an important role in protecting not only the shareholders' interest but also other stakeholders' interests against management's self-interests. To this extent, Hermalin and Weisbach (1991) suggested that the board of directors should provide solutions to solve the problems faced by modern companies.

Chobpichien et al. (2008) noted that independence, size, frequency of board meetings, and non-duality of the chief executive officer (CEO) are the important 
factors that determine the effectiveness of board that forces management to disclose more information to outside parties. Singh and Van der Zahn (2008) and Ruth, Emma and Marti'nez (2011) pointed out that the enhancement of board of directors in terms of board size, board composition, and leadership structure could improve board effectiveness and its capacity to monitor the management to the extent of increasing the possibility of providing more information about IC to outside investors. Cerbioni and Parbonetti (2007) suggested that the board is effective in improving the IC disclosure when it is small in size, has independent chairman with majority of its members also been independent, has active members in audit, nomination, and compensation committee. These elements, if present, would enhance the monitoring role of board of directors. However, it has been suggested that the optimal combination of these mechanisms can be considered better to reduce the agency cost and to protect the interest of all shareholders because the effectiveness of corporate governance is achieved via differen channels (Cai et al. 2008). According to Chobpichien et al. (2008) and Ward et al. (2009), it is important to look at corporate governance as a bundle of mechanisms to protect shareholder interests and not in isolation from each other because these governance mechanisms act in a complementary or substitutable fashion (Chobpichien et al. 2008). This is in addition to Hill (1999) who posited that it is desirable to have a system which consists of several checks and balances mechanisms, and none of them is accountable by itself to provide solution to all the problems faced by companies. Based on the above arguments, this study suggests that when the characters that enhance the effectiveness of board of directors increase, the level of IC disclosure also increases. Thus, the following hypothesis is proposed:

$\mathrm{H}_{1}$ There is a positive association between the effectiveness of the board of directors and IC disclosure.

\section{INFORMATION ASYMMETRY IN MODERATING BOARD OF} DIRECTORS AND IC DISCLOSURE RELATIONSHIP

According to Jensen and Meckling (1976) and Fama and Jensen (1983), outside directors are perceived as tools to protect the shareholders' interest through monitoring managerial opportunism and enhancing the level of disclosure that reduces agency risk (Bhojraj \& Sengupta 2003). However, McNulty, Roberts and Stiles (2002) argued that outside directors are always less informed regarding the company operations as compared to their executive colleagues due to their notable operating distance from management. Due to this reason, the outside directors are incapable of spending enough time with the executive colleagues and consequently suffer from information asymmetry by providing the outside directors with incomplete control (Mace 1971). Hill (1999) further expanded on the issue by stating that non-executive control is hampered through information asymmetry manipulated by management. This problem could escalate if the company is managed by large shareholders who have selfish agendas that are contrary to the outside shareholders' agendas, which consequently disallow the executive to provide more information for the outside directors (Fan \& Wong 2002). Thus, information asymmetry in the company hinders nonexecutive members from gathering necessary information on management activities e.g., information needed by the non-executive members for performance evaluation. Therefore, OCED (2009) suggested to policy makers in GCC to allow outside directors to easily obtain information that they needed in order to make the board governance effective in protecting all shareholders

From the discussion above, it can be observed that one of the reasons for the mixed results obtained by previous studies on the relationship between the effectiveness of board of directors and IC disclosure (Cerbioni \& Parbonetti 2007; Li et al. 2008; Taliyang \& Jusop 2011; Ruth et al. 2011) is information asymmetry. It is an indicator of entrenchment of management such that the lower the information, the lower the entrenchment of management. This would allow nonexecutives to participate in making decision and in controlling the management. With a high degree of information asymmetry, entrenchment of management will increase and the managers will play a significant role in the decision making while the non-executives would not be able to control managers because they do not have sufficient knowledge about the firm or the power delegated to them by shareholders is actually exercised by the management (Demb \& Neubaeuer 1992).

Based on hegemony theory, information asymmetry is one of the mechanisms for management control which influences the effectiveness of board of directors. This study proposes that, as the level of information asymmetry increases, the ability of board of directors to enforce the management on IC disclosure decreases. Therefore, in line with hegemony theory, the following hypothesis is proposed:

$\mathrm{H}_{2}$ The level of information asymmetry negatively moderates the relationship between the level of board of directors' effectiveness and IC disclosure.

\section{RESEARCH METHOD}

This study used secondary data on all listed banks in GCC Stock Exchange. The listed banks were chosen for this study because of their greater commitment and exposure to investors in respect of mandatory and voluntary reporting than unlisted banks. The samples in this study have the following criteria:

1. The banks published their annual report between 2008 and 2010 in their website.

2. The annual report was accessible and it contained complete information needed. 
Based on the above criteria, all Kuwaiti listed banks (11 banks) and several banks in other GCC countries are excluded from the sample. The final sample consists of 137 out of 210 banks which are composed as follows: UAE (43), Bahrain (34), Saudi (28), Oman (16) and Qatar (16).

\section{DEPENDENT VARIABLE: IC DISCLOSURE}

Categories of IC captured were based on the index developed in a recent study by Zaman Khan and Ali (2010) (see Table 1). The reasons for adopting Zaman Khan and Ali's framework are: First, they developed their framework based on Sveiby's framework, which has later been modified by Guthrie and Petty (2000). Guthrie and Petty's framework has been adopted and employed by other studies (e.g. Bozzolan et al. 2003; Vandemaele et al. 2005 ) with varying degrees of similarity. Zaman Khan and Ali's framework is more or less the same with Brennan (2001), April, Bosma and Deglon (2003), Abeyseker and Guthrie (2005), and Campbell and Abdul Rahman (2010). Second, Zaman Khan and Ali's framework was applied on banking sectors. As a result, only those items that were consistently identified as relevant and were likely to be disclosed by banks were included. Zaman Khan and Ali have removed some items from Sveiby's framework on the grounds that these would be better reported within the internal management reports of banks and that IC disclosure is a new phenomenon in the banking sector.

To measure IC disclosure, this study employed content analysis, which has also been used in the previous studies on IC disclosure (Guthrie, Petty \& Yongvanich 2004; $\mathrm{Li}$ et al. 2008). This is because content analysis allows repeatability and valid inferences from data according to the context (Krippendorf 1980). In order to increase the reliability of the scores, this study used the steps applied by Milne and Adler (1999), and Guthrie, Cuganesan and Ward (2008) as follows: First, the disclosure categories were adopted from well-grounded, relevant literature such as Zaman Khan and Ali (2010) who adapted their framework from well-grounded, relevant literature such as Sveiby (1997) and Guthrie and Petty (2000). Second, in order to increase the validity of content analysis, this study used the sentence as the measurement unit (Milne \& Adler 1999). Third, the coder underwent a sufficient period of training, and pilot study was conducted in order to reach an acceptable level of the reliability of the coding decisions (Guthrie et al. 2008).

\section{INDEPENDENT VARIABLES}

This study followed the direction of prior studies (e.g. Hanlon, Rajgopal \& Shevlin 2003; Brown \& Caylor 2006; Chobpichien et al. 2008; Singh \& Van der Zahn 2008) and used a composite governance score to measure the effectiveness of board of directors. The score is a composite measure that sums the value of the five dichotomous characteristics of the board to create a bankspecific summary measure of the effectiveness of board of directors. The higher score is an indicator of a higher effectiveness of the board of directors.

The five binary characteristics that are included in this measurement are board independence, board committees, board size, board meeting and CEO duality. In order to be consistent with the prior studies, this study viewed board which is smaller in size, has more independent boards that held higher frequency of meetings, is not chaired by the CEO, and has at least three sub-committees as effective board. For each of the components (except for non-duality and number of board committees), this study calculated the sample median. The value of one was assigned for an effective characteristic (i.e., companies below the sample median for board size and above the sample median for percentage of independent directors and frequency of meetings). We then summed these values with the score of one for non-duality and also one for board with at least three committees.

\section{MODERATING VARIABLE: INFORMATION ASYMMETRY}

Information asymmetry is an indicator of entrenchment of management; lower information is lower entrenchment of management, which allows non-executives to participate in making decision and controlling management (Mace 1971). According to Shleifer and Vishny (1988), the increase in the concentration of ownership leads to the increase in the entrenchment of management. This is because a major shareholder has sufficient voting power to appoint someone to be $\mathrm{CEO}$, directors or chairman

TABLE 1. IC Framework Adopted for the Study

\begin{tabular}{lll}
\hline Internal capital & External capital & Human capital \\
\hline Patent & Customers & Training \\
Copyright & Banks' market share & Employees' educational \\
Corporate culture & Business & qualification \\
Management philosophy & collaboration & Work related Knowledge \\
Management and & Franchising Licensing & Work related \\
technological process & Banks' reputation for services & Competencies \\
Information system & Bank name & Know how \\
networking system & & Entrepreneurial spirit \\
Financial relations & & \\
\hline
\end{tabular}

Source: Zaman Khan and Ali (2010: 56) 
(Shleifer \& Vishny 1988). Management entrenchment gives members, who act as the controlling shareholders, the right to extract benefits from the firm at the cost of minority shareholders (Shleifer \& Vishny 1988; Chrisman, Chua \& Sharma 2005). For example, Attig et al. (2006) hypothesized that large wedge between controlling rights and cash flow rights can increase the likelihood of selfish behavior of those who are in control. The controlling shareholders can do so by reducing or delaying the information availability so that other shareholders cannot interfere. The withholding information can also make the monitoring conducted by the board of directors less effective (Filatotchev, Lien \& Piesse 2005; Chen \& Nowland 2010) due to the outside directors are always less informed regarding company operations.

Glosten and Milgrom (1985) argued that information asymmetry becomes severe when there are chances of extracting private benefit. So, when percentage of minority ownership in company increases, the chances for controlling shareholders to extract private benefits will decrease and thus the problem of information asymmetry will not be severe (Bruggen, Vergauwen \& Dao 2009). In this case, the entrenchment of management will therefore decrease, thus the board of directors is able to control the management. This study used the percentage of minority ownership as proxy of information asymmetry. This means that the increase in the minority ownership in bank leads to the decrease information asymmetry and thus the board of directors is able to control the management.

\section{CONTROL VARIABLES}

The study used bank size, profitability, and leverage that have been used widely as control variables in the empirical literature of corporate governance. Following Al-Shammari and Al-Sultan (2010), this study measured firm leverage by dividing the total of liabilities by the total of assets and bank size was natural logarithm of total asset. Profitability was measured as the ratio of net income, before extraordinary items, to the total assets $(\mathrm{Li}$ et al. 2008).

\section{STATISTICAL ANALYSIS}

The study used hierarchical regression analysis that has been commonly used as technique in identifying moderating effects (Baron \& Kenny 1986; Frazier, Tix \& Baron 2004). According to Aiken and West (1991), to detect moderator effects, interaction terms must be created. The interaction term is the product of multiplying the independent variable with the moderator variable. So, interaction term raises concerns about the multicollinearity problem between interaction terms and their component terms. To avoid this problem, the independent and moderator variables were standardized (Frazier et al. 2004; Aguinis, Sturman \& Pierce 2008). Standardizing (i.e., z scoring) also makes it easier to interpret the effects of the predictor and moderator in a meaningful interpretation (Frazier et al. 2004; Aguinis et al. 2008).
After interaction terms have been created, everything is ready for conducting hierarchical multiple regression equation using SPSS to test for moderator effects. To do this, variables are entered into the regression equation through four steps. First step is to test the control variable, second step is to test the independent variable, the third step is to test the moderating variable, and the final step is to test the interaction terms of independent variable and moderating variable. The steps used were in accordance to the suggestion by Baron and Kenny (1986) and Frazier et al. (2004). The models are stated as follows:

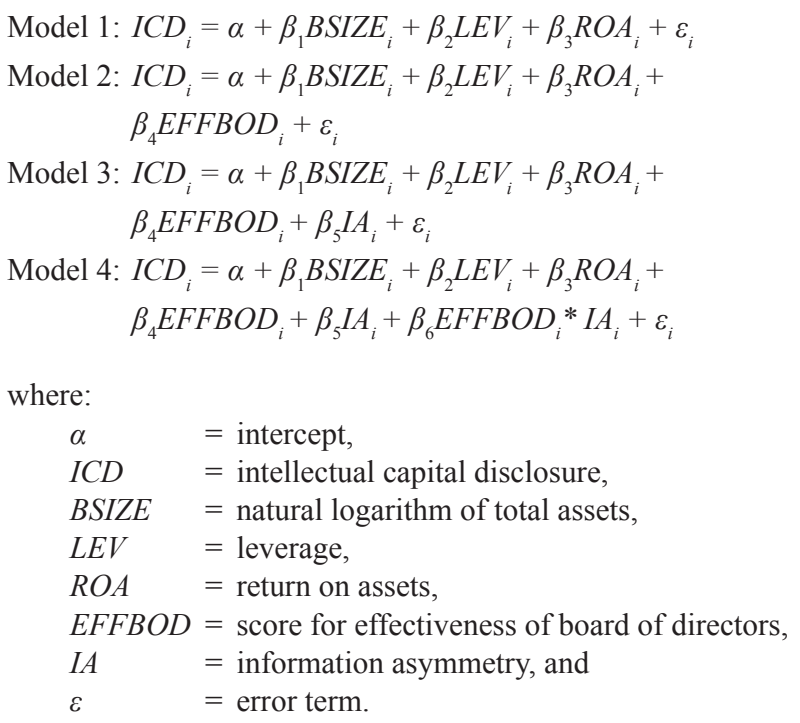

\section{EMPIRICAL RESULT}

\section{DESCRIPTIVE ANALYSIS}

In Table 2, Panel A presents the descriptive statistics of IC disclosure, in overall and categories. With regards to the overall of IC disclosure, Panel A in Table 2 shows that the average number of IC disclosure is 86.72 sentences. The maximum value is 175 sentences and the minimum value is 17 sentences. With respect to IC disclosure categories, the Panel A in Table 2 shows that the banks provided slightly greater number of information about internal capital at an average of 47.83 than both external capital and human capital disclosures, which scored 31.72 and 14.37 , respectively. This result is consistent with prior studies (e.g. Bozzolan et al. 2003; Brennan 2001; Ali, Khan \& Fatima 2008; Striukova, Unerman \& Guthrie 2008).

In Panel B of Table 2, the summary of the descriptive statistics for the independent, moderator, and control variables is presented. The panel shows that the average score of the effectiveness of board of directors is 2.53 . Further information is presented in Table 3 to show the frequency for each score. As shown in Table 3, the majority of GCC banks have effectiveness of board of directors' score of 2 (46 banks) and 3 (46 banks). Only five banks have the maximum score (i.e., 5) and only one bank has the minimum score (i.e., 0). Additionally, Table 
TABLE 2. Descriptive Statistics

\begin{tabular}{|c|c|c|c|c|c|}
\hline Variable & Minimum & Maximum & Median & Mean & Std. Deviation \\
\hline \multicolumn{6}{|l|}{ Panel A } \\
\hline Overall IC Disclosure & 17.00 & 175.00 & 31 & 86.72 & 35.21 \\
\hline Internal capital & 10.00 & 140.00 & 45 & 47.83 & 24.76 \\
\hline External capital & 6.00 & 75.00 & 29 & 31.72 & 16.81 \\
\hline Human capital & 0.00 & 46.00 & 9 & 14.37 & 12.51 \\
\hline \multicolumn{6}{|l|}{ Panel B } \\
\hline Effectiveness of board of directors & 0.00 & 5.00 & 2.00 & 2.53 & 1.06 \\
\hline Information asymmetry & 0.02 & 0.85 & 0.37 & 0.38 & 0.20 \\
\hline Return on Assets (ROA) & -0.06 & 0.10 & 0.02 & 0.02 & 0.02 \\
\hline Leverage & 0.10 & 0.91 & 0.79 & 0.72 & 0.19 \\
\hline Log of total asset & 7.36 & 10.89 & 9.75 & 9.81 & 0.67 \\
\hline
\end{tabular}

2 shows that minority shareholding which is a proxy of information asymmetry on average is $38 \%$. In terms of control variables, the Panel B in Table 2 shows that the $\log$ of total asset varies with a minimum value of 7.36 and a maximum value of 10.89 . The samples had an average leverage level of $72 \%$ and a ROA of $2 \%$. The negative sign in the ROA implies that some of the banks experienced a loss during the investigation period.

TABLE 3. Frequency Board of Directors' Effectiveness Score

\begin{tabular}{cc}
\hline EFFBOD & Frequency \\
\hline 0.00 & 1 \\
1.00 & 22 \\
2.00 & 46 \\
3.00 & 46 \\
4.00 & 17 \\
5.00 & 5 \\
\hline
\end{tabular}

Notes: EFFBOD is score of effectiveness of board of directors that is ranged from $0-5$ (highest). Score is measured by given value of one for each effective characteristic (i.e., non-duality and board with at least three committees, below the sample median for board size and above the sample median for percentage of independent directors and frequency of meetings. The sample median for board size is 9 , board independence 0.54 and 6 for board meeting.

\section{REGRESSION RESULTS}

As shown in Step 1 (Model 1), Table 4, when the bank size, leverage and ROA are used as control variables into regression model, the coefficient of determination $\left(\mathrm{R}^{2}\right)$ was found to be 0.23 , indicating that 0.23 of the level of IC disclosure can be explained by these control variables. The result also shows that bank size and leverage have significant relationship with IC disclosure. However, ROA is not related with IC. This result is consistent with the results obtained by Li et al. (2008).

Table 4 also shows that by adding the score of effectiveness of board in Step 2 (Model 2), the $\mathrm{R}^{2}$ increases to 0.26 . This change in $\mathrm{R}^{2}(0.03)$ is significant. This implies that the effectiveness of board of directors is positively associated with IC disclosure. This result supports agency theory and the arguments that as the level of effectiveness of board of directors increases, the level of IC disclosure increases (e.g. Cerbioni \& Parbonetti 2007; Singh \& Van der Zahn 2008).

Table 4 also shows that by adding information asymmetry in Step 3 (Model 3 ), $\mathrm{R}^{2}$ is not significantly changed. According to the model, the information asymmetry is not significantly related to IC disclosure. This result indicates that there is no major effect from the information asymmetry. This result is in line with the one obtained by Bruggen et al. (2009) where the information asymmetry was not significantly related to IC disclosure. To examine the influence of the information asymmetry on the score of effectiveness of board of directors -IC disclosure relationship, the interaction of information asymmetry with the score of effectiveness of board of directors was added in Step 4 (Model 4) in Table 4. As shown in the model, the interaction of information asymmetry with the score of effectiveness of board of directors is significantly related to IC disclosure. The $\mathrm{R}^{2}$ increases further from 0.26 to 0.31 . This change in $\mathrm{R}^{2}(0.05)$ is significant. This indicates that information asymmetry moderates the relationship between the effectiveness of board of directors and IC disclosure. In more specific words, the results suggest that, as information asymmetry decreases (i.e. the percentage of minority shareholder increases in the bank), the positive relationship between the effectiveness of board of directors and IC disclosure increases.

Figure 1 also illustrates the moderating effect of information asymmetry (percentage of minority shareholder) on the relationship between the effectiveness of board of directors and IC disclosure. It appears from the figure that lower information asymmetry (higher minority shareholder) is associated with higher IC disclosure. When the level of the effectiveness of board of directors is low, the level of IC disclosure is low in banks with high and low information asymmetry. However, when the level of the effectiveness of board of directors is high, the level of IC disclosure is higher in banks with low information asymmetry (higher percentage of minority shareholder) than in banks with high information asymmetry (percentage of minority shareholder). 
TABLE 4. Results of Hierarchical Regression Analysis

\begin{tabular}{|c|c|c|c|c|}
\hline & Model 1 & Model 2 & Model 3 & Model 4 \\
\hline LEV & $\begin{array}{c}0.41 * * * \\
(5.50)\end{array}$ & $\begin{array}{c}0.40 * * * \\
(5.10)\end{array}$ & $\begin{array}{c}0.40 * * * \\
(5.10)\end{array}$ & $\begin{array}{c}0.36 * * * \\
(4.54)\end{array}$ \\
\hline BSIZE & $\begin{array}{l}0.16^{*} \\
(1.98)\end{array}$ & $\begin{array}{l}0.16^{*} \\
(2.0)\end{array}$ & $\begin{array}{c}0.16^{*} \\
(2.0)\end{array}$ & $\begin{array}{c}0.12 \\
(1.49)\end{array}$ \\
\hline $\mathrm{ROA}$ & $\begin{array}{c}0.01 \\
(0.11)\end{array}$ & $\begin{array}{c}0.02 \\
(0.28)\end{array}$ & $\begin{array}{c}0.02 \\
(0.28)\end{array}$ & $\begin{array}{c}0.01 \\
(0.13)\end{array}$ \\
\hline EFFBOD & & $\begin{array}{l}0.17 * * \\
(2.20)\end{array}$ & $\begin{array}{c}0.17 * * \\
(1.99)\end{array}$ & $\begin{array}{c}0.09 \\
(1.04)\end{array}$ \\
\hline IA & & & $\begin{array}{c}0.05 \\
(0.06)\end{array}$ & $\begin{array}{c}0.06 \\
(0.07)\end{array}$ \\
\hline EFFBOD x IA & & & & $\begin{array}{c}0.25 * * \\
(2.95)\end{array}$ \\
\hline $\mathrm{R}^{2}$ & 0.23 & 0.26 & 0.26 & 0.31 \\
\hline Adjusted $\mathrm{R}^{2}$ & 0.21 & 0.24 & 0.24 & 0.28 \\
\hline $\mathrm{R}^{2}$ change & 0.23 & 0.03 & 0 & 0.05 \\
\hline F change & 12 & 4.8 & 0.04 & 8.7 \\
\hline Sig. of F change & 0 & 0.03 & 0.94 & 0 \\
\hline
\end{tabular}

Notes: $*, * *, * * *=p$-value $<.10, .05, .01$, respectively, one-tailed. The coefficient estimates (numbers in parenthesis are t-statistic) from the regressions. Abbreviation IA = information asymmetry, $\mathrm{LEV}=$ leverage, $\mathrm{BSIZE}=$ board size, $\mathrm{ROA}=$ rteurns on assets, $\mathrm{EFFBOD}=$ effectiveness of board of directors, EFFBOD x IA = the interaction of the two variables.

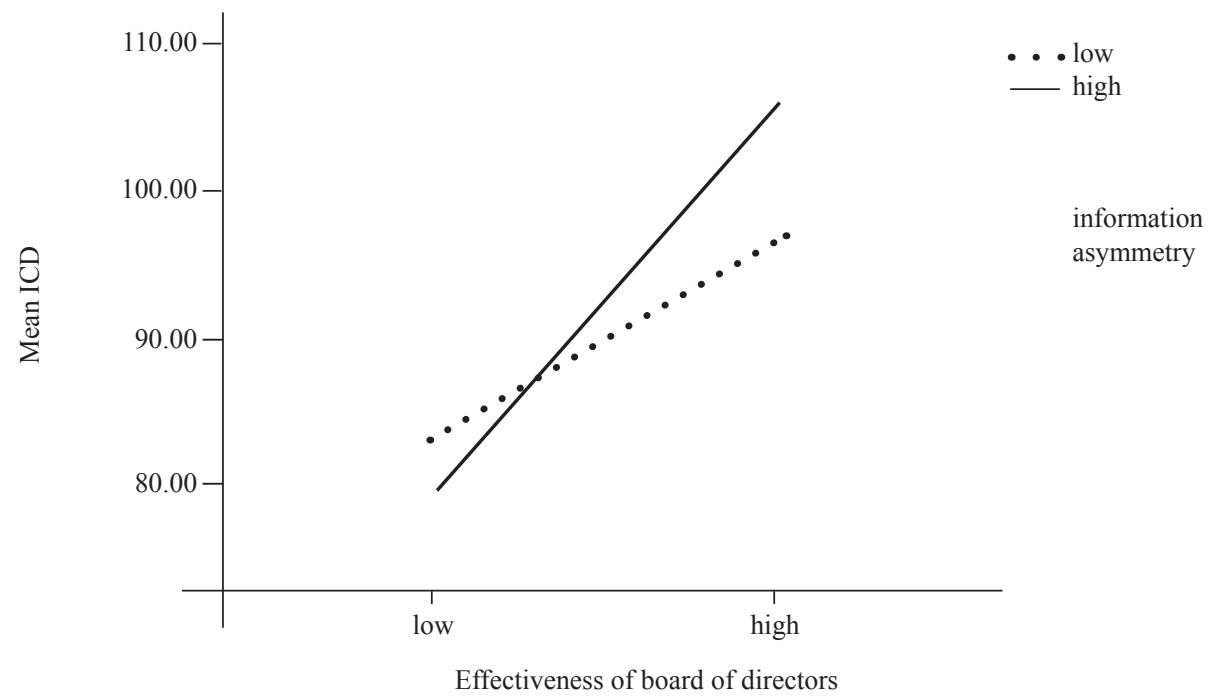

FIGURE 1. The Moderating Effect of Information Asymmetry

\section{DISCUSSION AND CONCLUSIONS}

Drawing on the argument that corporate governance should be examined as a bundle, this study suggests that the increase of the characters that enhance the effectiveness of board of directors leads to the increase in the level of voluntary disclosure. In addition, based on the arguments that the intensity of board of directors' monitoring to reduce the conflicts between the majority and minority shareholders through the increase of the level of disclosure is affected by information asymmetry (Boone et al. 2007; Linck et al. 2008), this study suggests that information asymmetry moderates the relationship between the effectiveness of board of directors and IC disclosure.
There are several important findings revealed in this study. First, this study finds that as the level of the effectiveness of board of directors increases, the level of IC disclosure in banks' annual reports increases. This result supports the agency theory and the idea that increase of the characters that enhance the effectiveness of board of directors leads to the increase in the level of voluntary disclosure.

Second, this study finds that information asymmetry moderates the relationship between the effectiveness of board of directors and IC disclosure. This result suggests that effective role that board of directors could play in enforcing management to disclose information about IC is affected by the level of information asymmetry. As the level of information asymmetry increases in bank, 
board of director is unlikely to be effective. This finding supports homogeny theory which suggests that boards are weak and inefficient in monitoring management because of their reliance on management in obtaining information about the company`s operations. Thus, in situations under which information asymmetry problem is high, board will be less effective.

The findings of the study are important for policy makers and investors as they confirm that the effectiveness of board of directors in enhancing the level of IC disclosure depends on the level of information asymmetry. Thus, policy makers should look for other mechanisms that motivate the management to enhance the IC disclosure in banks where the information asymmetry is a high. Findings of this study give investors sign that in situations under which information asymmetry is high, board of directors could not play effective role in enhancing IC disclosure.

This study has a number of limitations that might warrant future research. This study can be considered as an exploratory and thus more works are needed in specific areas to improve it. As the samples used in this paper only involve the GCC-listed banks, in future, more samples could be included for a longer period of time. The test of the hypotheses could also be extended to different type of firms (i.e., in other sectors) or for the same type of firms but in different context (i.e., other Arab countries or Asia). Second, this study did not examine the effect of the legal enforcement on IC disclosure due to the low legal protection of investor rights and legal enforcement in all the GCC. Legal protection of investor rights would affect policies of voluntary disclosure on IC. Thus, future researches should retest these hypotheses in different legal protection setting.

\section{REFERENCES}

Abeysekera, I. \& Guthrie, J. 2005. An empirical investigation of annual reporting trends of intellectual capital in Sri Lanka. Critical Perspectives on Accounting 16(3):151-163.

Agrawal, A. \& Knoeber, C.R. 1996. Firm performance and mechanisms to control agency problems between managers and shareholders. Journal of Financial and Quantitative Analysis 31(3): 377-397.

Aguinis, H., Sturman, M. \& Pierce, C. 2008. Comparison of three meta-analytic procedures for estimating moderator effects of categorical variables. Organizational Research Methods 11(9): 9-34.

Aiken, L. \& West, S. 1991. Multiple Regression: Testing and Interpreting Interactions. Newbury Park, CA: Sage.

Aktaruddin, M., Hossain, A., Hossain, M. \& Yao, L. 2009. Corporate governance and voluntary disclosure in corporate annual reports of Malaysian listed firms. The Journal of Applied Management Accounting Research 7(1): 1-20.

Al-Hassan, A., Oulidi, N. \& Khamis, M. 2010. The GCC banking sector: Topography analysis. Washington: International Monetary Fund IMF Working Paper Series.

Ali, M., Khan, M. \& Fatima, Z. 2008. Intellectual capital reporting practices: A study on selected companies in Bangladesh. Journal of Business Studies 29(1): 82-104.
Al-Muharrami, S., Matthews, K. \& Khabari, Y. 2006. Market structure and competitive conditions in the Arab GCC banking system. Journal of Banking \& Finance 30(12): 3487-3501.

Al-Shammari, B. \& Al-Sultan, W. 2010. Corporate governance and voluntary disclosure in Kuwait. International Journal of Disclosure and Governance 7(3): 262-280.

April, K. A., Bosma, P. \& Deglon, D. A. 2003. IC measurement and reporting: Establishing a practice in South African mining. Journal of Intellectual Capital 4(2): 165-180.

Attig, N., Fong, W., Gadhoum, Y. \& Lang, L. 2006. Effects of large shareholding on information asymmetry and stock liquidity. Journal of Banking \& Finance 30: 2875-2892.

Baron, R. \& Kenny, D. 1986. The moderator-mediator variable distinction in social psychological research: Conceptual, strategic, and statistical considerations. Journal of Personality and Social Psychology 51: 1173-1182.

Bhojraj, S. \& Sengupta, P. 2003. Effect of corporate governance on bond ratings and yields: The role of institutional investors and outside directors. Journal of Business 76: 455-475.

Boone, A., Casares Field, L., Karpoff, J. \& Raheja, C. 2007. The determinants of corporate board size and composition: An empirical analysis. Journal of Financial Economics 85(1): 66-101.

Bozzolan, S., Favotto \& Ricceri, F. 2003. Italian annual intellectual capital disclosure. Journal of Intellectual Capital 4(4): 543-558.

Brennan, N. \& Connell, B. 2000. Intellectual capital: Current issues and policy implications. Journal of Intellectual Capital 1(3): 206-240.

Brennan, N. 2001. Reporting intellectual capital in annual reports: Evidence from Ireland. Accounting, Auditing \& Accountability Journal 14(4): 423-436.

Brown, L.D. \& Caylor, M. 2006. Corporate governance and firm valuation. Journal of Accounting and Public Policy 25(4): 409-434.

Bruggen, A.,Vergauwen, P. \& Dao, M. 2009. Determinants of intellectual capital disclosure: evidence from Australia. Management Decision 47(2): 233-245.

Bukh, N., Nielsen, C., Gormsen, P. \& Mouritsen, J. 2005. Disclosure of information on intellectual capital in Danish IPO prospectuses. Accounting, Auditing and Accountability Journal 18 (6):713-732.

Cai, J., Liu, Y. \& Qian, Y. 2008. Information asymmetry and corporate governance. Drexel College of Business Research Paper Series.

Campbell, D. \& Abdul Rahman, M. 2010. A longitudinal examination of intellectual capital reporting in Marks \& Spencer annual reports, 1978-2008. The British Accounting Review 42(1): 56-70.

Cerbioni, F. \& Parbonetti, A. 2007. Exploring the effects of corporate governance on intellectual capital disclosure: An analysis of European biotechnology companies. European Accounting Review 16(4): 791-826.

Chahine, S. 2007. Activity-base diversification, corporate governance, and the market valuation of commercial banks in the Gulf Commercial Council. Journal of Management and Governance 11(4): 353-382.

Chen, E. \& Nowland, J. 2010. Optimal board monitoring in family-owned companies: Evidence from Asia. Corporate Governance: An International Review 18(1): 3-17.

Chobpichien, J., Haron, H. \& Ibrahim, D. 2008. The quality of board of directors, ownership structure and level of 
voluntary disclosure of listed companies in Thailand. Euro Asia Journal of Management 3(17): 3-39.

Chrisman, J., Chua, J. \& Sharma, P. 2005. Trends and directions in the development of a strategic management theory of the family firm. Entrepreneurship Theory and Practice 29: 555-575.

Demb, A. \& Neubauer, F. 1992. The corporate board: Confronting the paradoxes. In History of Management Thought: Corporate Governance, edited by, R.I. Tricker. Aldershot: Ashgate Publishing Limited.

Edvinson, L. \& Malone, M. 1997. Intellectual capital: The proven way to establish your company's real value by measuring its hidden brain power. London: Piatkus.

Fama, E. \& Jensen, M. 1983. Separation of ownership and control. Journal of Law and Economics 26(2): 301-325.

Fan, H. \& Wong, T. 2002. Corporate ownership structure and the informativeness of accounting earnings in East Asia. Journal of Accounting and Economics 33: 401-25.

Filatotchev, I., Lien, Y. \& Piesse, J. 2005. Corporate governance and performance in publicly listed, family-controlled firms: Evidence from Taiwan. Asia Pacific Journal of Management 22: 257-283.

Frazier, P., Tix, A. \& Barron, K. 2004. Testing moderator and mediator effects in counseling psychology research. Journal of Counseling Psychology 51(1): 115-134.

Glosten, L. \& Milgrom, P. 1985. Bid, ask and transaction prices in a specialist market with heterogeneously-informed traders. Journal of Financial Economics 14: 71-100.

Guthrie, J. \& Petty, R. 2000. Intellectual capital: Australian annual reporting practices. Journal of Intellectual Capital $1(2 / 3)$.

Guthrie, J., Cuganesan, S. \& Ward, L. 2008. Industry specific social and environmental reporting: The Australian food and beverage industry. Accounting Forum 32: 1-15.

Guthrie, J., Petty, R. \& Yongvanich, K. 2004. Using content analysis as a research method to inquire into intellectual capital reporting. Journal of Intellectual Capital 5(2): 282-293.

Hanlon, M., Rajgopal, S. \& Shevlin, T. 2003. Are executive stock options associated with future earnings? Journal of Accounting and Economics 36(1-3): 3-43.

Hermalin, B. \& Weisbach, M. 1991. The effects of board composition and direct incentives on firm performance. Financial Management 20: 101-112.

Hill, J.G. 1999. Deconstructing Sunbeam-Contemporary issues in corporate governance. University of Cincinnati Law Review 67: 099-1127.

Jensen, M. \& Meckling, W. 1976. Theory of the firm: Managerial behavior, agency costs and ownership structure. Journal of Financial Economics 3(4): 305-360.

Kaplan, R. \& Norton, D. 1992. The balanced scorecard-measures that drive performance. Harvard Business Review 70(1): 71-79.

Krippendorff, K. 1980. Content analysis: An introduction to its methodology. Beverly Hills: Sage Publications.

Kristandl, G. \& Bontis, N. 2007. The impact of voluntary disclosure on cost of in a temporal setting. Journal of Intellectual Capital 8(4): 577-594.

Li, J., Pike, R. \& Haniffa, R. 2008. Intellectual capital disclosure and corporate governance structure in UK firms. Accounting and Business Research 38(2): 137-159.

Li, J., Mangena, M. \& Pike, R. 2012. The effect of audit committee characteristics on intellectual capital disclosure. Accounting and Business Research 44(2): 98-110.
Linck, S., Netter, J. \& Yang, T. 2008. The determinants of board structure. Journal of Financial Economics 87(2): 308-328.

Mace, M. 1971. Directors: Myth and reality. Boston, MA: Harvard University Graduate School of Business Administration.

Marr, B., Mouritsen, J. \& Bukh, P. 2003. Perceived wisdom. Financial Management July/August 32.

McNulty, A., Roberts, J. \& Stiles, P. 2002. Creating accountability within the board: the work of the effective the non-executive director. Department for Trade and Industry.

Milne, M. \& Adler, R. 1999. Exploring the reliability of social and environmental disclosures content analysis. Accounting, Auditing \& Accountability Journal 12(2): 237-256.

OCED. 2009. Policy brief on improving corporate governance of banks in the Middle East and North Africa region.

Ranjith, A. 2007. The impact of intellectual capital on investors' capital gain on shares: an empirical investigation in Thai banking, finance \& insurance sector. Journal of Internet Banking and Commerce 12(1): 111-134.

Rediker, K. \& Seth, A. 1995. Boards of directors and substitution effects of alternative governance mechanisms. Strategic Management Journal 16: 85-99.

Ruth, H., Emma, G. \& Martı'nez, I. 2011. Corporate governance and intellectual capital disclosure. Journal of Business Ethics 100: 483-495.

Singh, I. \& Van der Zahn, J. 2008. Determinants of intellectual capital disclosure in prospectuses of initial public offerings. Accounting and Business Research 38(5): 409-431.

Shleifer, M. \& Vishny,W. 1988. Management ownership and market valuation: an empirical analysis. Journal of Financial Economics 20: 293-315.

Striukova, L. Unerman, J. \& Guthrie, J. 2008. Corporate reporting of intellectual capital: evidence from UK companies. British Accounting Review 40(4): 297-313.

Sullivan, P. 2000. Profiting from intellectual capital. Journal of Knowledge Management 3(2): 132-143.

Sveiby, K. 1997. The intangible assets monitor. Journal of Human Resource Costing \& Accounting 2(1): 73-97.

Taliyang, M. \& Jusop, M. 2011. Intellectual capital disclosure and corporate governance structure: evidence in Malaysia International. Journal of Business and Management $6(12)$.

Vandemaele, S.N., Vergauwen, P. \& Smits, A. J. 2005. Intellectual capital disclosure in the Netherlands, Sweden and the UK: A longitudinal and comparative study. Journal of Intellectual Capital 6(3): 417-426

Vergauwen, P. \& Alem, F. 2005. Annual report IC disclosures in the Netherlands, France and Germany. Journal of Intellectual Capital 6(1): 89-104.

Ward, A. Brown, J. \& Rodriguez, D. 2009. Governance bundles, firm performance and the substitutability and complementarily of governance mechanisms. Corporate Governance: An International Review 17(5): 646-660.

Williams, S.M. 2001. Are intellectual capital performance and disclosure practices related? Journal of Intellectual Capital 2(3): 192-203.

Yi, A. \& Davey, H. 2010. Intellectual capital disclosure in Chinese (Mainland) companies. Journal of Intellectual Capital 11(3): 326-347.

Young, N., Peng, M., Ahlstrom, D., Bruton, D. \& Jiang, Y. 2008. Corporate governance in emerging economies: A review of the principal-principal perspective. Journal of Management Studies 45(1): 196-220. 
Zaman Khan, M. \& Ali, M. 2010. An empirical investigation and users' perceptions on intellectual capital reporting in banks: Evidence from Bangladesh. Journal of Human Resource Costing \& Accounting 14(1): 48-69.

Zuaini Ishak

School of Accounting, College of Business

Universiti Utara Malaysia

06001 Sintok, Kedah, Malaysia

E-mail: zuaini@uum.edu.my

Abood Mohammad Al-Ebel (corresponding author)

School of Accounting, College of Business

Universiti Utara Malaysia

06001 Sintok, Kedah, Malaysia

E-mail: aboodmo@yahoo.com 
